\title{
Satellite-derived submarine melt rates and mass balance (2011-2015) for Greenland's largest remaining ice tongues
}

\author{
Nat Wilson ${ }^{1,2}$, Fiammetta Straneo ${ }^{3, a}$, and Patrick Heimbach ${ }^{4}$ \\ ${ }^{1}$ MIT-WHOI Joint Program in Oceanography/Applied Ocean Science and Engineering, Cambridge, Massachusetts, USA \\ ${ }^{2}$ Geology and Geophysics Department, Woods Hole Oceanographic Institution, Woods Hole, Massachusetts, USA \\ ${ }^{3}$ Physical Oceanography Department, Woods Hole Oceanographic Institution, Woods Hole, Massachusetts, USA \\ ${ }^{4}$ Jackson School of Geosciences and Institute for Computational Engineering and Sciences, \\ University of Texas at Austin, Austin, Texas, USA \\ ${ }^{a}$ now at: Scripps Institution of Oceanography, UCSD, La Jolla, CA, USA
}

Correspondence to: Nat Wilson (njwilson23@gmail.com)

Received: 30 May 2017 - Discussion started: 27 June 2017

Revised: 7 October 2017 - Accepted: 23 October 2017 - Published: 5 December 2017

\begin{abstract}
Ice-shelf-like floating extensions at the termini of Greenland glaciers are undergoing rapid changes with potential implications for the stability of upstream glaciers and the ice sheet as a whole. While submarine melting is recognized as a major contributor to mass loss, the spatial distribution of submarine melting and its contribution to the total mass balance of these floating extensions is incompletely known and understood. Here, we use high-resolution WorldView satellite imagery collected between 2011 and 2015 to infer the magnitude and spatial variability of melt rates under Greenland's largest remaining ice tongues - Nioghalvfjerdsbræ (79 North Glacier, 79N), Ryder Glacier (RG), and Petermann Glacier (PG). Submarine melt rates under the ice tongues vary considerably, exceeding $50 \mathrm{ma}^{-1}$ near the grounding zone and decaying rapidly downstream. Channels, likely originating from upstream subglacial channels, give rise to large melt variations across the ice tongues. We compare the total melt rates to the influx of ice to the ice tongue to assess their contribution to the current mass balance. At Petermann Glacier and Ryder Glacier, we find that the combined submarine and aerial melt approximately balances the ice flux from the grounded ice sheet. At Nioghalvfjerdsbræ the total melt flux $\left(14.2 \pm 0.96 \mathrm{~km}^{3} \mathrm{a}^{-1}\right.$ w.e., water equivalent) exceeds the inflow of ice $\left(10.2 \pm 0.59 \mathrm{~km}^{3} \mathrm{a}^{-1}\right.$ w.e. $)$, indicating present thinning of the ice tongue.
\end{abstract}

\section{Introduction}

Mass loss from ice sheets is often greatest at the marine termini (Truffer and Motyka, 2016). Here, ice shelves and ice tongues are hypothesized to influence the stability of the upstream glaciers and thus of the entire ice sheet (e.g. Dupont and Alley, 2005; Furst et al., 2016). For these reasons, monitoring and understanding processes at marine outlets is key to understanding past and predicting future ice sheet variability.

In Greenland, floating ice tongues currently protrude, or have recently protruded, from the termini of several major outlet glacier systems. However, warming air and ocean temperatures since the mid-1990s have accompanied the reduction or disappearance of most of Greenland's floating ice tongues. This includes the rapid retreat and collapse of the Jakobshavn Glacier (Jakobshavn Isbræ) beginning in 1998 (Motyka et al., 2010). Beginning in 2012, the floating ice tongue of Zachariæ Isbræ, one of the largest in Greenland, has been in a phase of retreat and collapse (Mouginot et al., 2015). Partial loss of the ice tongue has occurred at Petermann Glacier (PG) in northwestern Greenland via a series of major calving events (Falkner et al., 2011; Münchow et al., 2014), and Mouginot et al. (2015) and Kjeldsen et al. (2015) have reported thinning at Nioghalvfjerdsbræ $(79 \mathrm{~N})$ in northeast Greenland. In all cases, changes in submarine melting have been identified as the likely driver of these ice tongue changes (e.g. Holland et al., 2008; Motyka et al., 2011; Münchow et al., 2016). 
Unfortunately, accurately assessing the submarine melt terms in the mass balance of ice tongues is challenging. This is partly due to the difficulty in making extensive in situ measurements (Straneo et al., 2012a) and partly due to the trade-offs in spatial and temporal resolution made by existing remote measurement platforms. However, given the recent changes in ice tongues and ice shelves in Greenland and Antarctica and the role they have in buttressing upstream ice flow (Dupont and Alley, 2005), understanding the spatial variability and magnitude of submarine melting is needed to predict future ice sheet variability and sea level rise (Joughin et al., 2012).

We address the observational gap by estimating current melt rates under Greenland's three largest remaining ice tongues: Nioghalvfjerdsbræ, Ryder Glacier (RG), and Petermann Glacier. The 79 North Glacier is the largest existing ice tongue in Greenland by area with a $65 \mathrm{~km}$ long floating ice section confined within a $20 \mathrm{~km}$ wide fjord (Fig. 1) and is grounded at a depth of $700 \mathrm{~m}$ (Mayer et al., 2000). It is one of three outlet glaciers of the northeast Greenland ice stream (Fahnestock et al., 1993), together with neighbouring Storstrømmen glacier and Zachariæ Isbræ. While Zachariæ Isbræ has undergone both recent collapse and acceleration, change at $79 \mathrm{~N}$ has been less visible, with no major calving events despite the high melt rates first inferred by Mayer et al. (2000). Recently though, several studies have reported that thinning at $79 \mathrm{~N}$ appears to have taken place during the $21 \mathrm{st}$ century (Kjeldsen et al., 2015; Mouginot et al., 2015).

In northwestern Greenland, RG is an ice tongue roughly $25 \mathrm{~km}$ long within a $10 \mathrm{~km}$ wide fjord and grounded around $500 \mathrm{~m}$ depth (Joughin et al., 1999). RG episodically experiences both large calving events and "surge" episodes (Joughin et al., 1996). Further west, PG is the second largest ice tongue in Greenland by area. PG also experiences episodic major calving events (Falkner et al., 2011) with recent examples from 2001, 2008, 2010, and 2012. The grounding line depth at PG is approximately $500 \mathrm{~m}$ (Johnson et al., 2011), and rapid basal melting was noted by Rignot (1996). For both 79N and PG, steady state estimates suggest that the ice tongue's mass balance is dominated by submarine melting (Mayer et al., 2000; Johnson et al., 2011; Falkner et al., 2011; Münchow et al., 2014).

Recent estimates of melt rates for these ice tongues are derived from flux gate or flux divergence methods (e.g. Rignot and Steffen, 2008; Enderlin and Howat, 2013). These approaches rely on an assumption of steady state, in which the ice tongue is neither thinning or thickening. Münchow et al. (2014) use ICESat and IceBridge data to show that nonsteady melt was important at PG prior to calving. Furthermore, while broad generalizations of the melt rate patterns are currently available from Mayer et al. (2000) and Seroussi et al. (2011), there are no published efforts to carefully map the distribution of melting at $79 \mathrm{~N}$ and $\mathrm{RG}$ over the entire ice tongue.
To address this, we compute the Lagrangian hydrostatic ice thickness change over the period 2011-2015 from digital elevation models (DEMs) constructed from WorldView satellite imagery. The results from this analysis allow us to both map the spatial variability of melting and to determine the current ice tongue mass balance. This method has been applied in Antarctica (e.g. Dutrieux et al., 2013; Moholdt et al., 2014), but never before to Greenland's ice tongues. Contemporary velocity estimates come from optical feature tracking applied to the same imagery used for the elevation models. We combine the material ice thickness change with flow divergence fields to compute the sum of surface and submarine ice tongue melt rates, accounting for dynamic thinning. The surface component of the transient melt, estimated from $0.76-2.0 \mathrm{~m}$ w.e. (water equivalent) depending on the ice tongue, was extracted from version 2.3 of the regional atmospheric climate model (RACMO2.3, Noël et al., 2015) and subtracted from the net melt rate to yield estimated submarine melt rates. We present the melt rates as a temporal average over the years for which data are available. Compared to previous approaches that use flux gate approaches and rely on steady state assumptions, this method more easily incorporates transient thinning or thickening of ice tongues.

\section{Methodology}

\subsection{Data sources and preparation}

We used optical image pairs from WorldView-1, WorldView2, and WorldView-3 satellites, collected over the period 2011-2015 and distributed by the Polar Geospatial Center at the University of Minnesota. We orthorectified these images with the Greenland Ice Mapping Project Digital Elevation Model (Howat et al., 2014) and then constructed new DEMs using the open-source NASA Ames Stereo Pipeline software (Shean et al., 2016). Vertical and horizontal errors in the DEMs are reduced by re-referencing non-glaciated regions to a composite DEM constructed by averaging all available DEMs. Shean et al. (2016) demonstrates that errors in WorldView DEMs are highly correlated, such that co-registration to a common data source removes much of the relative uncertainty.

Although the accuracy of existing tide models is in most cases unknown, we subtract the tidal elevation predicted from the AOTIM-5 tide model (Padman and Erofeeva, 2004). The distance between the most landward edge of the grounding zone and the point where the ice tongue is in hydrostatic equilibrium is on the order of a few kilometres (Brunt et al., 2010). Therefore, the influence of tides will be fully reflected in the ice tongue elevation beyond a narrow buffer zone at the grounding zone, which we exclude from the full analysis (see below). The comparison between the AOTIM-5 estimates and a short record collected in 2009 at 79N (G. Hamil- 


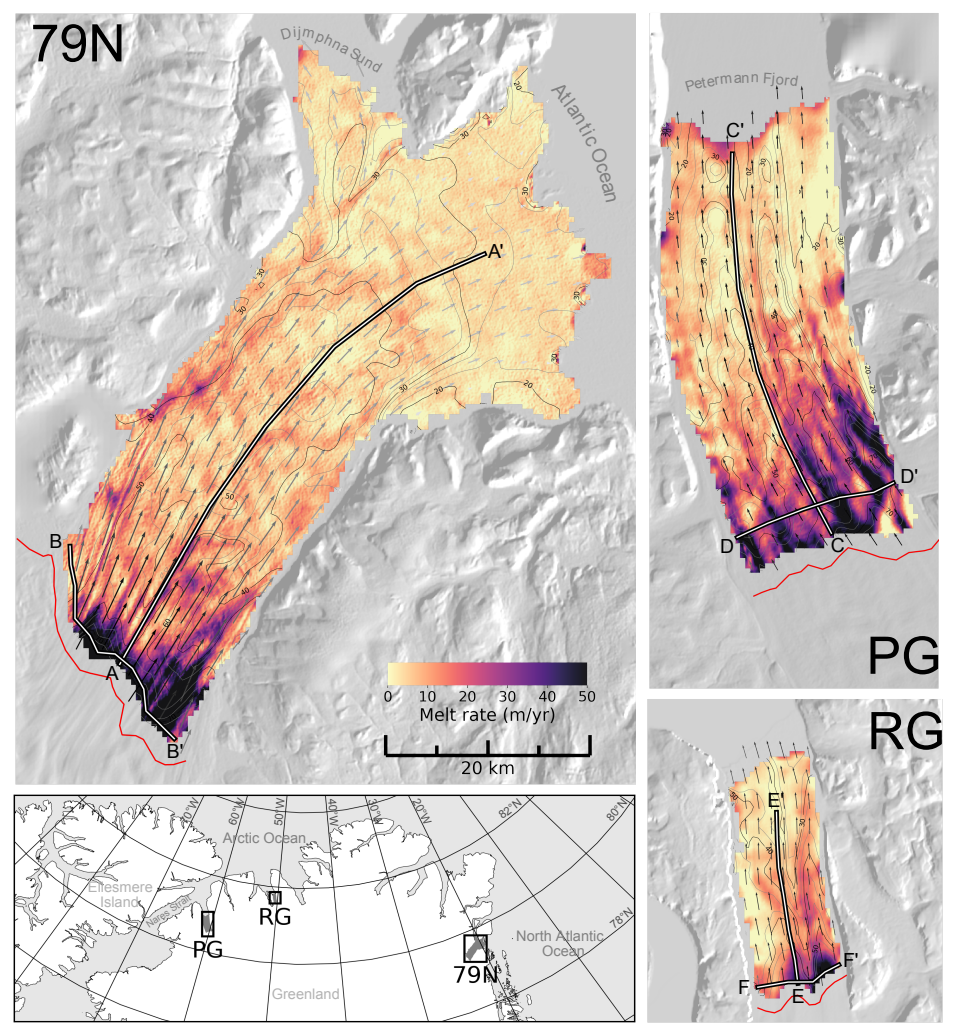

Figure 1. Map of submarine melt rates from Greenland's major ice tongues derived from WorldView satellite DEMs. The colour shading shows regions of rapid submarine melting, while the arrows indicate ice flow directions. The red line approximates the grounding line. The inset map in the lower left provides regional context.

ton and L. Stearns, personal communication, 2015) reveals an offset in the tide model of approximately $0.2 \mathrm{~m}$.

\subsection{Velocity}

Over an ice tongue, where basal and lateral stresses are negligible and ice aspect ratio is small, surface velocity is close to the depth-averaged velocity (Weertman, 1957). We compute a grid of correlation offsets by comparing image chips extracted from overlapping hillshaded maps computed from each DEM. We compute the cross correlation between extracted image chips and then use a Gaussian subpixel peakfinding calculation (Debella-Gilo and Kääb, 2011) to estimate displacement. The cross correlation at the peak normalized by the cross correlation standard deviation is retained as a measure of correlation quality. To reduce the area that must be searched for correlation over long temporal baselines, we estimate feature displacement from the MEaSUReS ice velocity dataset (Joughin et al., 2010) and extract image chips representing a small neighbourhood around these estimates.

\subsection{Melt rates}

Mass conservation of an ice tongue requires that

$\frac{\partial h}{\partial t}+\nabla \cdot(\boldsymbol{u} h)=\dot{a}$

where $h$ is the ice tongue thickness, $\boldsymbol{u}$ is the depth-averaged velocity, and $\dot{a}$ is the rate of ice thickness change due to combined surface and submarine mass balance. Ice thickness is inferred by assuming hydrostatic equilibrium over the floating ice tongue with a constant ice density of $920 \mathrm{~kg} \mathrm{~m}^{-3}$ and a constant seawater density of $1028 \mathrm{~kg} \mathrm{~m}^{-3}$. Hydrostasy is a good approximation over sufficiently long horizontal length scales and shallow tongue thickness gradients (Brunt et al., 2010). Immediately downstream of the grounding line the hydrostatic assumption is less justified, so we exclude data within a few kilometres of the grounded ice sheet. The BedMachine mass-conserving bed elevation dataset (Morlighem et al., 2014) serves as a guide to identify where the ice reaches flotation.

The surface component of the mass balance is extracted from the RACMO2.3 (Noël et al., 2015) model product. We use a single average melt rate computed over the pe- 
Table 1. Digital elevation model (DEM) counts. Counts of DEMs used for each ice tongue, combined with counts of DEM pairs used for elevation differencing.

\begin{tabular}{lrr}
\hline Glacier & $\begin{array}{r}\text { DEM } \\
\text { count }\end{array}$ & $\begin{array}{r}\text { DEM pair } \\
\text { count }\end{array}$ \\
\hline $79 \mathrm{~N}$ & 108 & 915 \\
RG & 36 & 211 \\
PG & 97 & 751 \\
\hline
\end{tabular}

riod 2011-2015 for each ice tongue, which is appropriate for mean melt rates computed over multiple years.

By neglecting the time derivative in ice thickness, the steady state melt rate can be estimated from the flux divergence alone. For example, Seroussi et al. (2011) and Enderlin and Howat (2013) have applied this method to Greenland's marine-terminating glaciers. To include the time derivative in Eq. (1) and, in so doing, account for dynamic thickening or thinning of the ice tongue, we compare pairs of ice thickness estimates separated by a temporal baseline. If an Eulerian reference frame is used, this approach is susceptible to temporal aliasing of elevation variations advected along with ice flow. In a Lagrangian framework, temporal aliasing can be avoided as done previously with satellite altimetry data (Moholdt et al., 2014) and stereogrammetric elevation maps (Dutrieux et al., 2013). In this case, the mass balance equation is written in terms of the material time derivative,

$$
\frac{\mathrm{D} h}{\mathrm{D} t}+h \nabla \cdot \boldsymbol{u}=\dot{a}
$$

The Lagrangian framework has the additional advantage of avoiding the explicit calculation of an ice thickness derivative. Scenes for correlation and melt rate extraction are selected by searching the list of available DEMs for pairs that overlap by minimum of $50 \mathrm{~km}^{2}$ and that are separated in time by between 180 and 600 days (Table 1). A full listing of scenes used may be found in the Supplement, as well as details regarding their spatial (Supplement Fig. S1) and temporal (Fig. S2) distribution. We compute a temporal mean by averaging over average monthly binned estimates of $\mathrm{D} h / \mathrm{D} t$ (January-December) in order to offset bias due to the optical imagery being more available during seasons with more daylight.

\subsection{Grounding line fluxes}

We estimate the flux of ice from the grounded ice sheet into the floating ice tongue from the correlation-derived ice velocity and ice tongue thickness estimates over a flux gate at the downstream end of the grounding zone. Retaining the assumption from above that glacier velocity is invariant with depth, the total grounding line flux $\Phi$ is

$\Phi=\int_{a}^{b} \hat{u}(x) h(x) \mathrm{d} x$,

where $\hat{u}$ is the grounding line normal velocity and limits $a$ and $b$ are as close as possible to the glacier margins. We note that our results are more conservative than other estimates made further upstream, because some ice has melted by the time it crosses the upstream gate.

\subsection{Errors and uncertainties}

Uncertainty in the time-averaged melt estimates that we derive is due to measurement error, DEM co-registration and correlation errors, errors associated with the tide-corrected ocean elevation, and temporal variability in the ice tongue surface elevation due to accumulation. We make the assumption that these effects are unbiased and attempt to quantify the combined effect of these error sources using a jackknife resampling scheme. This provides uncertainty estimates for the computed melt rates and submarine melt fluxes. As the melt rates are generated from a large number of WorldView DEM pairs, we generate new melt rates by excluding individual DEMs and recomputing the relevant measures using the remaining subset of DEMs. This accounts for sources of random measurement error. Uncertainties reported in the text and figures represent 1 standard deviation around the computed mean value. Uncertainty in the flux gate volumes is expressed by including the variance from the full set of generated DEMs in the calculation of ice thickness at the flux gate. Some additional error is due to non-random effects such as downstream firn densification, which would yield melt overestimates. We expect this to be small as the ice tongues considered are well below the equilibrium line and any remaining firn layer is expected to be thin and assumed constant. This is supported by field data described by Dutrieux et al. (2014) indicating firn compaction (at PG) to be negligible over a 1-year period.

A source of biased error derives from the assignment of Lagrangian melt rates incurred over a trajectory to a single point. In Fig. 1, we assign the melt to the original (upstream) measurement location, which tends to shift the melt estimates slightly upstream in map representations. Based on the ice tongue velocities and temporal baselines used, this upstream bias may be up to a few kilometres in the extreme case that all melt actually occurs at the final (downstream) location.

The spatial scales at which ice thickness variability (and melt rate variability) may be diagnosed from surface elevation data is physically limited by the melting timescale and ice viscosity. To characterize the accuracy of our ice thickness estimates empirically, we have compared the hydrostatic ice thickness to radar measurements from the MCoRDS echo sounder flown as part of the Operation IceBridge program from 2010 to 2012 (Leuschen et al., 2010). These data are 

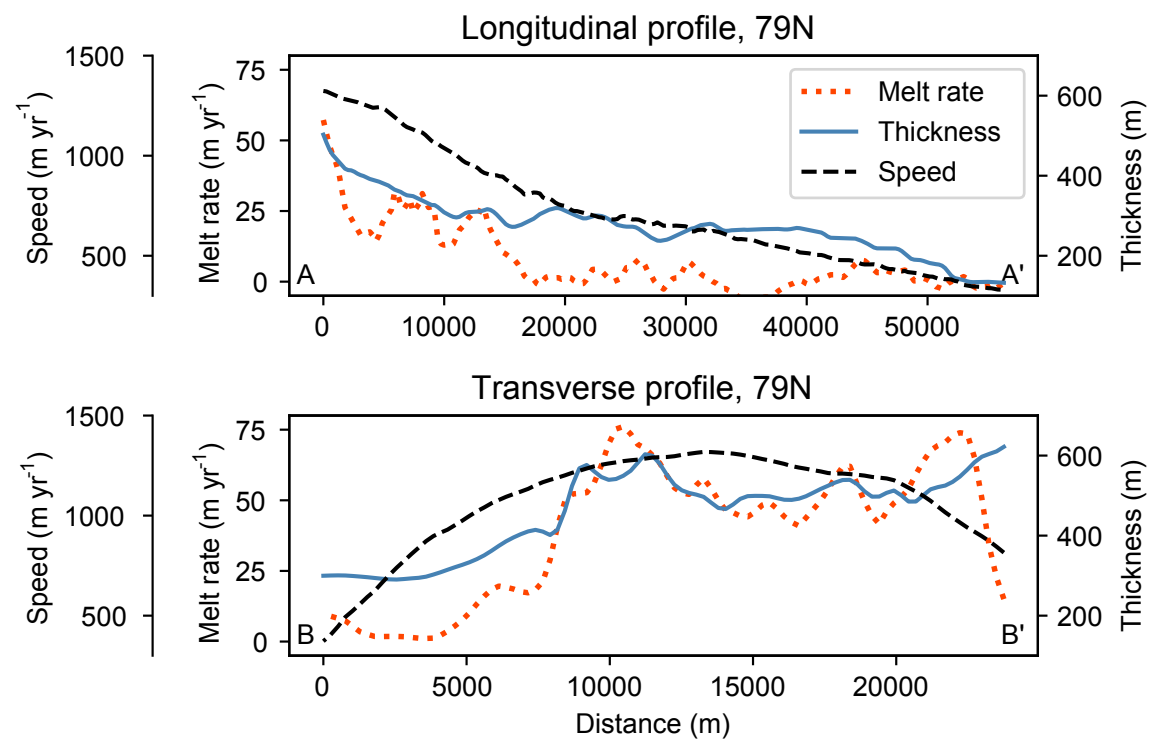

Figure 2. Velocity, melt rate, and ice thickness profiles for $79 \mathrm{~N}$. The longitudinal profile is along the glacier centreline. The transverse profile is taken approximately $1 \mathrm{~km}$ downstream of the upstream flux gate.

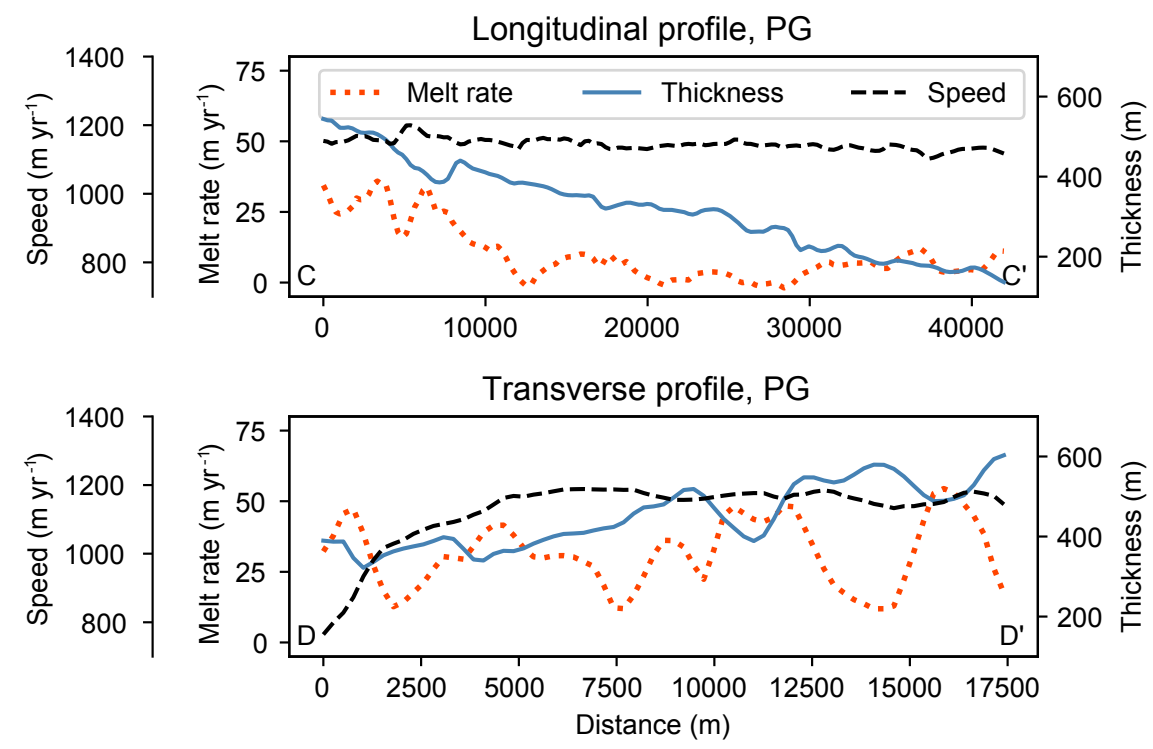

Figure 3. Velocity, melt rate, and ice thickness profiles for PG. The longitudinal profile is outside of a long sub-shelf channel. The transverse profile is taken approximately $1 \mathrm{~km}$ downstream of the upstream flux gate.

limited to only a few lines over the ice tongues, but match the ice thickness inferred from the DEMs with a coefficient of determination of 0.93 . We expect errors due to nonhydrostatic portions of the ice tongue to be small away from the grounded ice when averaged over coarse grids as in Fig. 1 or the entire ice tongue as in Table 2; however, limitations due to the assumption of hydrostasy should be kept in mind when considering small-scale features in the results.

\section{Results}

Melt rates for the three ice tongues indicate that the largest melt rates occur near the grounding line (Fig. 1) and decay within $10 \mathrm{~km}$ down-glacier from the upstream boundary of our analysis. Maximum melt rates at $79 \mathrm{~N}$ drop from 50 $60 \mathrm{~m} \mathrm{yr}^{-1}$ near the grounding line to $15 \mathrm{~m} \mathrm{yr}^{-1} 15 \mathrm{~km}$ downstream (Fig. 2). Further downstream, melt rates at $79 \mathrm{~N}$ drop 

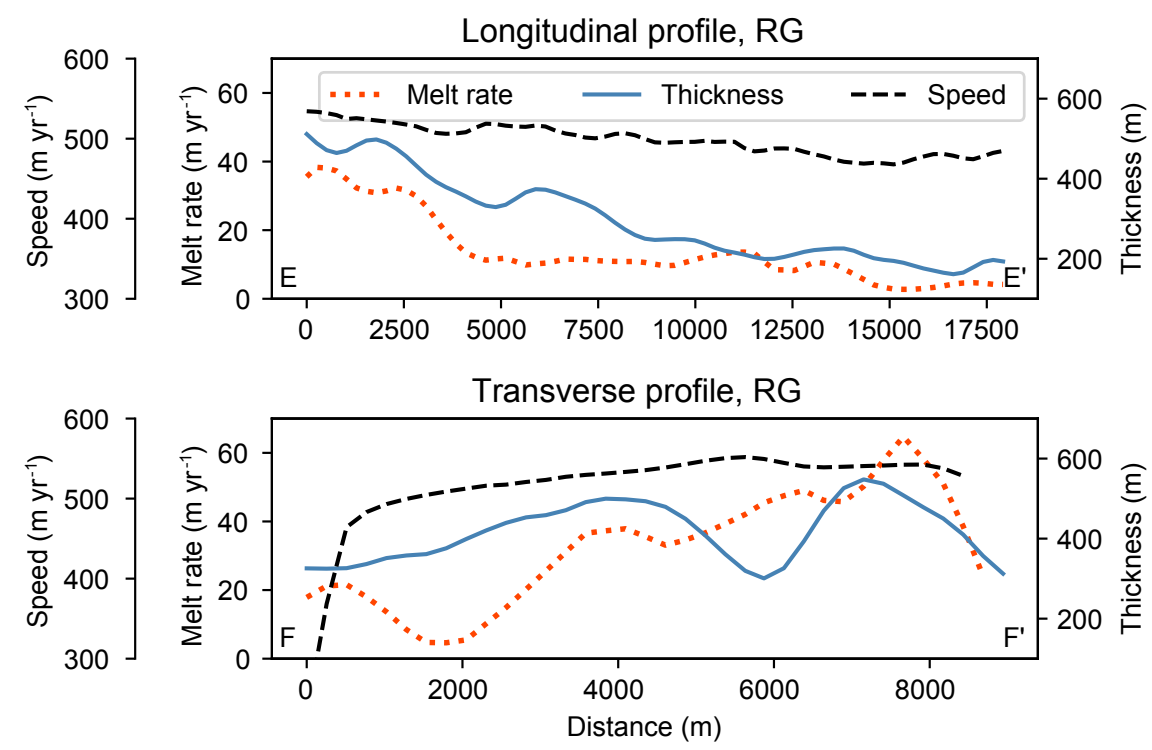

Figure 4. Velocity, melt rate, and ice thickness profiles for RG. The longitudinal profile is computed along a transect to the west of the major sub-shelf channel. The transverse profile is taken approximately $1 \mathrm{~km}$ downstream of the upstream flux gate.

Table 2. Volume fluxes for Greenland's major ice tongues, in freshwater equivalent. Total melt flux uncertainties are 1 standard deviation around measurements described here. Surface melt flux uncertainty is estimated from Noël et al. (2015). Submarine melt flux uncertainty is derived from total and surface melt flux uncertainty.

\begin{tabular}{lrrrrr}
\hline Glacier & $\begin{array}{r}\text { Volume } \\
\mathrm{km}^{3}\end{array}$ & $\begin{array}{r}\text { Inflowing ice } \\
\mathrm{km}^{3} \mathrm{yr}^{-1}\end{array}$ & $\begin{array}{r}\text { Total melt flux } \\
\mathrm{km}^{3} \mathrm{yr}^{-1}\end{array}$ & $\begin{array}{r}\text { Surface melt flux } \\
\mathrm{km}^{3} \mathrm{yr}^{-1}\end{array}$ & $\begin{array}{r}\text { Submarine melt flux } \\
\mathrm{km}^{3} \mathrm{yr}^{-1}\end{array}$ \\
\hline $79 \mathrm{~N}$ & 314 & $10.2 \pm 0.59$ & $14.2 \pm 0.96$ & $2.3 \pm 1.3$ & $11.9 \pm 1.6$ \\
RG & 51.0 & $1.9 \pm 0.12$ & $2.0 \pm 0.12$ & $0.25 \pm 0.17$ & $1.8 \pm 0.21$ \\
PG & 215 & $10.8 \pm 0.52$ & $11.7 \pm 1.2$ & $1.7 \pm 0.68$ & $10.0 \pm 1.4$ \\
\hline
\end{tabular}

to near zero. Slightly lower grounding zone melt rates are obtained for Petermann Glacier (40-50 $\mathrm{m} \mathrm{yr}^{-1}$ ), decreasing to a background rate of $10 \mathrm{~m} \mathrm{yr}^{-1}$ over a distance of $15-$ $20 \mathrm{~km}$ (Fig. 3). At RG, maximum melt rates near the grounding line are similar to those observed at PG; melt rates away from the grounding zone are in the range of $10-20 \mathrm{~m} \mathrm{yr}^{-1}$ (Fig. 4). These results are qualitatively consistent with aggregated rates obtained by previous studies (e.g. Mayer et al., 2000; Rignot and Steffen, 2008; Münchow et al., 2014).

In addition to this general decrease of melting away from the grounding zone, our results also show smaller-scale variations in melt rate on the scale of a few kilometres. At $79 \mathrm{~N}$, the fastest melting occurs near the southern two-thirds of the grounding zone and lower along the northern third (Fig. 2). The largest melt rates correspond to the thickest and fastest moving part of the ice stream. Large variability in melt rates in the across-tongue direction is also observed near the grounding zones of RG and PG. In particular, large melt rates (in excess of $50 \mathrm{~m} \mathrm{yr}^{-1}$ ) near the grounding zone of RG occur at the head of an incised channel associated with a 15-20 m elongate depression in surface elevation (Figs. 1 and 4). Melt rates on the west side of the grounding zone at RG are much lower in spite of similar ice thickness and draft. Recent bed elevation inversions by Morlighem et al. (2014) indicate that the region of rapid melting identified at $R G$ is at the end of a bedrock trough that reaches over $100 \mathrm{~km}$ upstream beneath the Greenland Ice Sheet. At PG, the melt rates patterns also appear to vary on a scale similar to the channelized geometry of the ice tongue base (Fig. 3), consistent with the broad spatial patterns derived from a steady state ice flux divergence approach (Rignot and Steffen, 2008) and comparable to radar-derived results (Dutrieux et al., 2014).

The annual surface melt rate predicted at $79 \mathrm{~N}$ by RACMO2.3 over the period $2011-2015$ is $1.5 \mathrm{ma}^{-1}$ w.e. Multiplying this by the ice tongue surface area of $1600 \mathrm{~km}^{2}$ suggests that submarine melting accounts for approximately $80 \%$ of the annual non-calving mass loss at $79 \mathrm{~N}$. We compute the ice volume flux passing from the grounded ice sheet through the point where the ice tongue becomes hydrostatic to equal $10.2 \pm 0.59 \mathrm{~km}^{3} \mathrm{yr}^{-1}$ w.e. This may be smaller than 


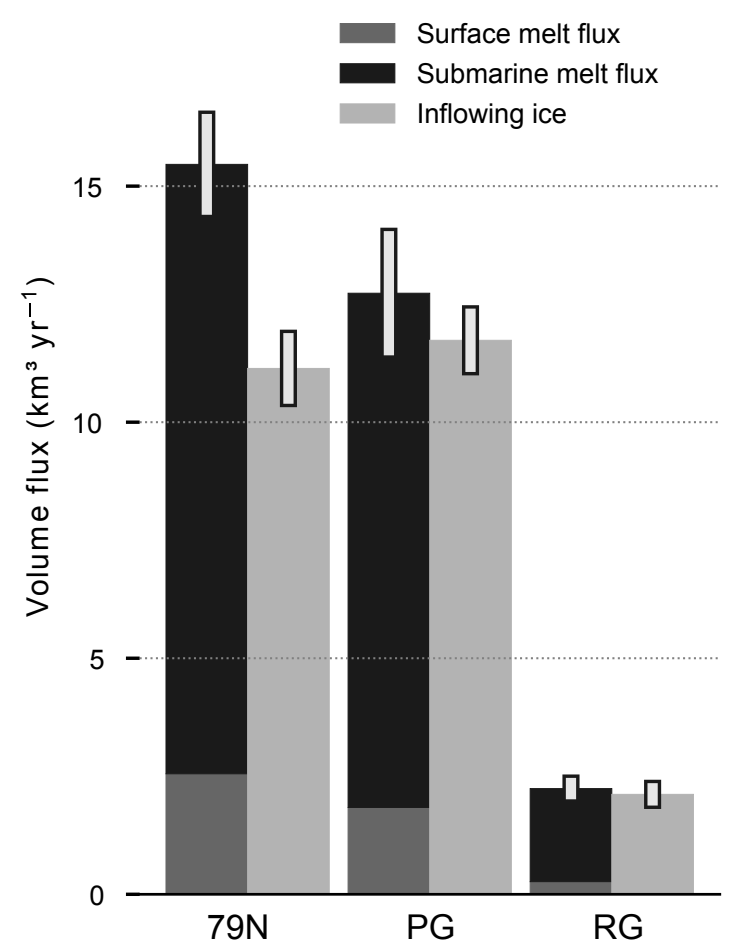

Figure 5. Comparison of ice volume fluxes. Melt flux and grounding line volume flux for each floating ice tongue are shown, with melt fluxes partitioned between submarine and subaerial components. Error bars represent 1 standard deviation above and below the estimate.

the $12 \pm 1 \mathrm{~km}^{3} \mathrm{yr}^{-1}$ reported by Rignot and Steffen (2008) because of our exclusion of a non-hydrostatic buffer around the actual grounding line. We find that the incoming ice volume is $70 \%$ of the observed melt flux within the region considered (14.2 $\pm 0.96 \mathrm{~km}^{3} \mathrm{yr}^{-1}$ w.e.), providing direct evidence that the ice tongue is melting at a faster rate than ice is being replenished from upstream (Fig. 5). Excluding calving, the annual net volume loss is $1.3 \%$ of the ice tongue's total volume. The imbalance between melting and advective replenishment of ice volume at $79 \mathrm{~N}$ is consistent with the thinning diagnosed from aerial imagery (Kjeldsen et al., 2015) and by comparing ice thickness derived from radar measurements during the 1990s and the 2010-2014 period (Mouginot et al., 2015).

By contrast, the grounding line flux at RG of $1.9 \pm$ $0.12 \mathrm{~km}^{3} \mathrm{yr}^{-1}$ w.e., which is slightly smaller than a previously reported (Rignot et al., 1997) value of $2.3 \mathrm{~km}^{3} \mathrm{yr}^{-1}$, is not significantly different from the total melt flux $(2.1 \pm$ $0.12 \mathrm{~km}^{3} \mathrm{yr}^{-1}$ w.e.). Similarly, at PG, which lost substantial area from 2001 to 2012 , the present combined observed melt fluxes $\left(11.7 \pm 1.2 \mathrm{~km}^{3} \mathrm{yr}^{-1}\right.$ w.e. $)$ are only slightly larger than the grounding line fluxes $\left(10.8 \pm 0.52 \mathrm{~km}^{3} \mathrm{yr}^{-1}\right.$ w.e.). Excluding calving, the annual net volume loss is $0.4 \%$ of the current ice tongue volume. As a result, we do not observe submarine melting at PG to be a driver of substantial net volume loss in its current configuration. However, based on a conservative estimate of melting under the former terminus of PG of $5-10 \mathrm{~m} \mathrm{yr}^{-1}$ and a calved area of approximately $250 \mathrm{~km}^{2}$, we estimate that the pre- 2010 melt flux may have been around $13 \mathrm{~km}^{3} \mathrm{yr}^{-1}$ w.e. It is therefore possible that the imbalance between melting and advective replenishment was greater prior to 2010 .

In all cases, we find a significant correlation between high melt rates and either ice tongue draft or ice tongue basal slope (Fig. 6). Given that draft and slope co-vary, it is interesting that the three ice tongues studied above differ in how the relationship between melt rates and draft and slope is expressed. At $79 \mathrm{~N}$, the relationship with slope is perhaps the weakest of the three, with high melt rates inferred even in regions of low basal slope. In general, most of $79 \mathrm{~N}$ is of very low slope, which appears to correspond with the lowest average melt rates of the three glaciers. Given this, the large mass imbalance at $79 \mathrm{~N}$ is a result of its large area rather than anomalously high average melt rates. In contrast, RG and PG have more similar distributions of basal slope.

\section{Discussion}

At all ice tongues the highest melt rates are found near the grounding line. This is consistent with the presence of relatively warm, dense waters of Atlantic origins on the nearby continental shelves and fjords (Straneo et al., 2012b). The in situ temperature of these waters can exceed $1{ }^{\circ} \mathrm{C}$ at $79 \mathrm{~N}$ (Wilson and Straneo, 2015), while those at PG in the northwest are consistently measured below $0.5^{\circ} \mathrm{C}$ (Rignot and Steffen, 2008; Münchow et al., 2016). To our knowledge, no ocean temperatures have been recorded near RG. Nevertheless, profiles collected in 2006 from the continental shelf $150 \mathrm{~km}$ away measured maximum temperatures below $300 \mathrm{~m}$ near $0.25^{\circ} \mathrm{C}$ (Steele, 2016). We expect the melt rate at the grounding depth to vary both with the water temperature above the freezing point (the thermal forcing), which in turn varies with pressure, and with factors that regulate the heat transfer across the ice-ocean boundary layer including ice slope and subglacial discharge (Jenkins, 2011; Straneo and Cenedese, 2015). Assuming that the ocean temperature at the grounding depth is equal to that observed in the fjords (and on the shelf for RG) and equal to $1,0.5$, and $0.25^{\circ} \mathrm{C}$ for $79 \mathrm{~N}$, $\mathrm{PG}$, and RG, respectively, and grounding depths of 700, 500, and $450 \mathrm{~m}$, we estimate the thermal forcing for these three systems to be about $3.4,2.7$, and $2.5^{\circ} \mathrm{C}$. In a broad sense, the melt rates near the grounding zone are consistent with differences in thermal forcing computed at the three ice tongues.

Thermal forcing aside, we also expect higher melting at steeper basal slopes due to the larger entrainment in rising melt water plumes (Little et al., 2009). Again our derived melt rates are largely consistent with this overall pattern but 

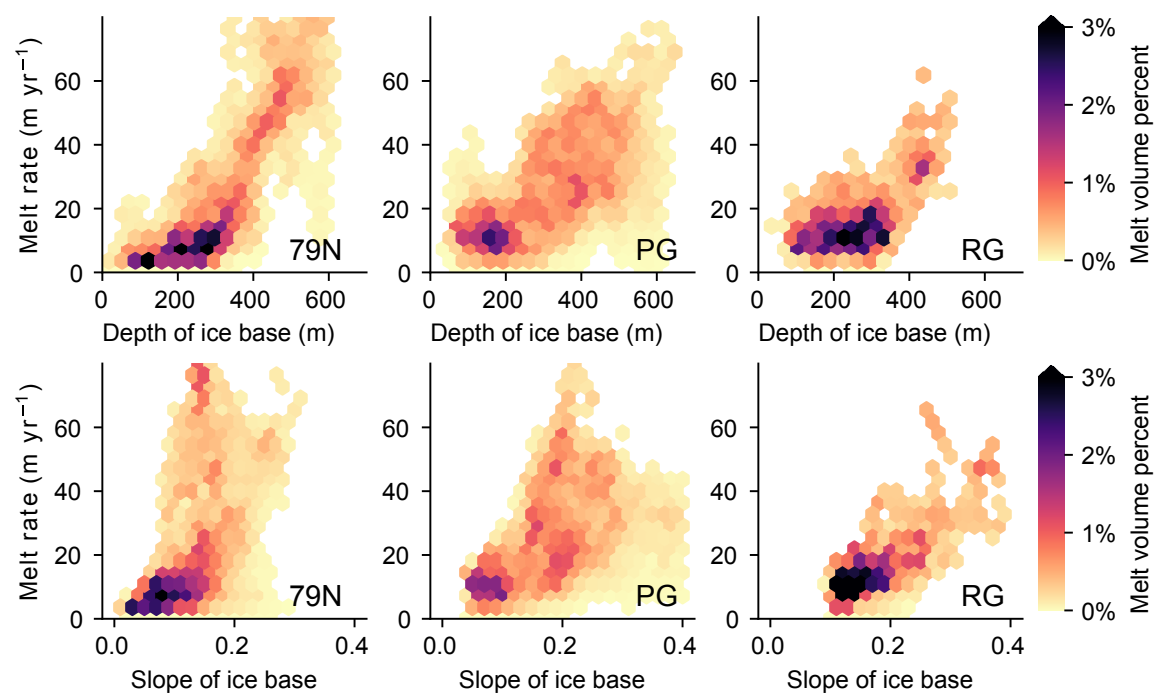

Figure 6. Relationships between estimated melt rates and the depth and slope of the ice tongue base. Shading serves as a visual guide to the density of observations in each cell.

suggest that there is no simple relationship between slope and melt rate.

Our results also indicate that these tongues exhibit a large lateral variability in melt rates due to the presence of basal channels. The detection of channelization using our methodology is limited by non-hydrostatic behaviour around narrow channels and the potential for drifting snow to accumulate in surface troughs associated with channels, and so those that we do detect tend to be large. At RG, the deep central channel along the base of the ice tongue appears to be a product of high melt rates and may also concentrate them in a positive feedback. The lower advection rates at RG may also make it more susceptible to developing deep channels, as the rate of replenishment of ice from upstream is lower. At PG, ice advection rates at the grounding line are similar to $79 \mathrm{~N}$, and so the presence of deep channels must be due to either more intense grounding line melting or more active maintenance by submarine melting along the length of the ice tongue (e.g. Gladish et al., 2012).

\section{Conclusions}

Our results highlight high spatial heterogeneity in melt rates beneath Greenland's ice tongues in both the along-flow and the across-flow directions. This latter component of spatial variability is typically ignored in models, but is likely to be important to accurately predict ice tongue and buttressing sensitivities to ocean temperature and ice geometry changes. We also show that PG and RG are in their current geometries close to maintaining their total volume, with grounding line influxes balancing inferred melting. We find that in spite of apparently minor changes in surface area in recent decades at $79 \mathrm{~N}$, net mass losses there are the highest of the remaining large ice tongues in Greenland. While our mass deficit estimates are based on an average over a relatively short (4 year) time span, high rates of mass loss lead us to speculate that major changes will take place at $79 \mathrm{~N}$ in the future as the ice tongue thins and eventually becomes ungrounded at its terminus. This could have important implications for buttressing of the inland portion of the outlet glacier that is the exit of the northeast Greenland ice stream.

Code and data availability. The satellite data used in this research are available subject to the data licensing requirements of the Polar Geospatial Center. Lists of the images used will be provided upon request. The code used to analyze the satellite images (Wilson, 2017) is available publicly at https://bitbucket.org/njwilson23/ worldview_processing or upon request.

\section{The Supplement related to this article is available online at https://doi.org/10.5194/tc-11-2773-2017-supplement.}

Author contributions. NW developed the code, performed the WorldView data analysis, and was the primary contributor to the text of the manuscript. FS actively contributed ideas and also submitted text for the manuscript. $\mathrm{PH}$ provided guidance by contributing helpful advice on the scientific ideas and feedback on the manuscript.

Competing interests. The authors declare that they have no conflict of interest. 
Acknowledgements. Nat Wilson, Fiammetta Straneo, and Patrick Heimbach were supported by NASA NNX13AK88G and NSF OCE 1434041. WorldView-1, 2, and 3 imagery were made available by the Polar Geospatial Center at the University of Minnesota and DigitalGlobe. Gordon Hamilton and Leigh Stearns provided GPS data from 79N. RACMO2.3 data were kindly made available by Michiel van den Broeke. David Shean contributed helpful advice and discussion regarding the processing of WorldView imagery with the NASA Ames Stereo Pipeline.

Edited by: Olivier Gagliardini

Reviewed by: two anonymous referees

\section{References}

Brunt, K. M., Fricker, H. A., Padman, L., Scambos, T. A., and O'Neel, S.: Mapping the grounding zone of the Ross Ice Shelf, Antarctica, using ICESat laser altimetry, Ann. Glaciol., 51, 7179, https://doi.org/10.3189/172756410791392790, 2010.

Debella-Gilo, M. and Kääb, A.: Sub-pixel precision image matching for measuring surface displacements on mass movements using normalized cross-correlation, Remote Sens. Environ., 115, 130-142, https://doi.org/10.1016/j.rse.2010.08.012, 2011.

Dupont, T. K. and Alley, R. B.: Assessment of the importance of ice-shelf buttressing to ice-sheet flow, Geophys. Res. Lett., 32, L04503, https://doi.org/10.1029/2004gl022024, 2005.

Dutrieux, P., Vaughan, D. G., Corr, H. F. J., Jenkins, A., Holland, P. R., Joughin, I., and Fleming, A. H.: Pine Island glacier ice shelf melt distributed at kilometre scales, The Cryosphere, 7, 15431555, https://doi.org/10.5194/tc-7-1543-2013, 2013.

Dutrieux, P., De Rydt, J., Jenkins, A., Holland, P. R., Ha, H. K., Lee, S. H., Steig, E. J., Ding, Q., Abrahamsen, E. P., and Schröder, M.: Strong sensitivity of Pine Island iceshelf melting to climatic variability, Science, 343, 174-178, https://doi.org/10.1126/science.1244341, 2014.

Enderlin, E. M. and Howat, I. M.: Submarine melt rate estimates for floating termini of Greenland outlet glaciers (2000-2010), J. Glaciol., 59, 67-75, https://doi.org/10.3189/2013JoG12J049, 2013

Fahnestock, M., Bindschadler, R., Kwok, R., and Jezek, K.: Greenland ice sheet surface properties and ice dynamics from ERS-1 SAR imagery, Science, 262, 1530-1534, https://doi.org/10.1126/science.262.5139.1530, 1993.

Falkner, K. K., Melling, H., Münchow, A. M., Box, J. E., Wohlleben, T., Johnson, H. L., Gudmandsen, P., Samelson, R., Copland, L., Steffen, K., Rignot, E., and Higgins, A. K.: Context for the recent massive Petermann Glacier calving event, Eos, 92, 117-118, https://doi.org/10.1029/2011EO140001, 2011.

Furst, J. J., Durant, G., Gillet-Chaulet, F., Tavard, L., Rankl, M., and Gagliardini, O.: The safety band of Antarctic ice shelves, Nat. Clim. Change, 6, 479-482, https://doi.org/10.1038/nclimate2912, 2016.

Gladish, C. V., Holland, D. M., Holland, P. R., and Price, S. F.: Iceshelf basal channels in a coupled ice/ocean model, J. Glaciol., 58, 1227-1244, https://doi.org/10.3189/2012JoG12J003, 2012.

Holland, D. M., Thomas, R. H., De Young, B., Ribergaard, M. H., and Lyberth, B.: Acceleration of Jakobshavn Isbræ triggered by warm subsurface ocean waters, Nat. Geosci., 1, 659-664, https://doi.org/10.1038/ngeo316, 2008.

Howat, I. M., Negrete, A., and Smith, B. E.: The Greenland Ice Mapping Project (GIMP) land classification and surface elevation data sets, The Cryosphere, 8, 1509-1518, https://doi.org/10.5194/tc-8-1509-2014, 2014.

Jenkins, A.: Convection-Driven Melting near the Grounding Lines of Ice Shelves and Tidewater Glaciers, J. Phys. Oceanogr., 41, 2279-2294, https://doi.org/10.1175/JPO-D-11-03.1, 2011.

Johnson, H. L., Münchow, A., Falkner, K. K., and Melling, H.: Ocean circulation and properties in Petermann Fjord, Greenland, J. Geophys. Res.-Oceans, 116, C01003, https://doi.org/10.1029/2010JC006519, 2011.

Joughin, I., Tulaczyk, S., Fahnestock, M., and Kwok, R.: A mini-surge on the Ryder Glacier, Greenland, observed by satellite radar interferometry, Science, 274, 228-230, https://doi.org/10.1126/science.274.5285.228, 1996.

Joughin, I., Fahnestock, M., Kwok, R., Gogineni, P., and Chris, A.: Ice flow of Humboldt, Petermann and Ryder Gletscher, northern Greenland, J. Glaciol., 45, 231-241, https://doi.org/10.3189/S0022143000001738, 1999.

Joughin, I., Smith, B. E., Howat, I. M., Scambos, T., and Moon, T.: Greenland flow variability from icesheet-wide velocity mapping, J. Glaciol., 56, 415-430, https://doi.org/10.3189/002214310792447734, 2010.

Joughin, I., Alley, R. B., and Holland, D. M.: Ice-sheet response to oceanic forcing, Science, 338, 1172-1176, https://doi.org/10.1126/science.1226481, 2012.

Kjeldsen, K. K., Korsgaard, N. J., Björck, A. A., Khan, S. A., Box, J. E., Funder, S., Larsen, N. K., Bamber, J. L., Colgan, W., van den Broecke, M. R., Siggard-Andersen, M.-L., Nuth, C., Schomacker, A., Andresen, C. S., Willerslev, E., and Kjær, K. H.: Spatial and temporal distribution of mass loss from the Greenland Ice Sheet since AD 1900, Nat. Lett., 528, 396400, https://doi.org/10.1038/nature16183, 2015.

Leuschen, C., Gogineni, P., F., Rodriguez-Morales, Paden, J., and Allen, C.: IceBridge MCoRDS L2 Ice Thickness, Version 1, National Snow and Ice Data Center Distributed Active Archive Center, https://doi.org/10.5067/GDQ0CUCVTE2Q, http://nsidc.org/ data/irmcr2, last access: 12 June 2016, 2010.

Little, C. M., Gnanadesikan, A., and Oppenheimer, M.: How ice shelf morphology controls basal melting, J. Geophys. Res., 114, C12007, https://doi.org/10.1029/2008JC005197, 2009.

Mayer, C., Reeh, N., Jung-Rothenhäusler, F., Huybrechts, P., and Oerter, H.: The subglacial cavity and implied dynamics under Nioghalvfjerdsfjorden Glacier, NE-Greenland, Geophys. Res. Lett., 27, 2289-2292, https://doi.org/10.1029/2000GL011514, 2000.

Moholdt, G., Padman, L., and Fricker, H. A.: Basal mass budget of Ross and Filchner-Ronne ice shelves, Antarctica, derived from Lagrangian analysis of ICESat altimetry, J. Geophys. Res.-Earth, 119, 2361-2380, https://doi.org/10.1002/2014JF003171, 2014.

Morlighem, M., Rignot, E., Mouginot, J., Seroussi, H., and Larour, E.: Deeply incised submarine glacial valleys beneath the Greenland ice sheet, Nat. Geosci., 7, 418-422, https://doi.org/10.1038/ngeo2167, 2014.

Motyka, R. J., Fahnestock, M., and Truffer, M.: Volume change of Jakobshavn Isbræ, West Green- 
land: 1985-1997-2007, J. Glaciol., 56, 635-646, https://doi.org/10.3189/002214310793146304, 2010.

Motyka, R. J., Truffer, M., Fahnestock, M., Mortensen, J., Rysgaard, S., and Howat, I.: Submarine melting of the 1985 Jakobshavn Isbræ floating tongue and the triggering of the current retreat, J. Geophys. Res.-Earth, 116, F01007, https://doi.org/10.1029/2009JF001632, 2011.

Mouginot, J., Rignot, E., Scheuchl, B., Fenty, I., Khazendar, A., Morlighem, M., Buzzi, A., and Paden, J.: Fast retreat of Zachariæ Isstrøm, northeast Greenland, Science, 350, 13571361, https://doi.org/10.1126/science.aac7111, 2015.

Münchow, A., Padman, L., and Fricker, H. A.: Interannual changes of the floating ice shelf of Petermann Gletscher, North Greenland from 2000 to 2012, J. Glaciol., 60, 489-499, https://doi.org/10.3189/2014JoG13J135, 2014.

Münchow, A., Padman, L., Washam, P., and Nicholls, K. W.: The ice shelf of Petermann Gletscher, North Greenland and its connection to the Arctic and Atlantic oceans, Oceanography, 29, 8495 , https://doi.org/10.5670/oceanog.2016.101, 2016.

Noël, B., van de Berg, W. J., van Meijgaard, E., Kuipers Munneke, P., van de Wal, R. S. W., and van den Broeke, M. R.: Evaluation of the updated regional climate model RACMO2.3: summer snowfall impact on the Greenland Ice Sheet, The Cryosphere, 9, 1831-1844, https://doi.org/10.5194/tc-9-1831-2015, 2015.

Padman, L. and Erofeeva, S.: A barotropic inverse tidal model for the Arctic Ocean, Geophys. Res. Lett., 31, 102303, https://doi.org/10.1029/2003GL019003, 2004.

Rignot, E.: Tidal motion, ice velocity and melt rate of Petermann Gletscher, Greenland, measured from radar interferometry, J. Glaciol., 42, 476-485, https://doi.org/10.3189/S0022143000003464, 1996.

Rignot, E. and Steffen, K.: Channelized bottom melting and stability of floating ice shelves, Geophys. Res. Lett., 35, L02503, https://doi.org/10.1029/2007GL031765, 2008.

Rignot, E. J., Gogineni, S. P., Krabill, W. B., and Ekholm, S.: North and Northeast Greenland ice discharge from satellite radar interferometry, Science, 276, 934-937, https://doi.org/10.1126/science.276.5314.934, available at: http://science.sciencemag.org/content/276/5314/934, 1997.
Seroussi, H., Morlighem, M., Rignot, E., Larour, E., Aubry, D., Dhia, H. B., and Kristensen, S. S.: Ice flux divergence anomalies on 79north Glacier, Greenland, Geophys. Res. Lett., 38, L09501, https://doi.org/10.1029/2011GL047338, 2011.

Shean, D. E., Alexandrov, O., Moratto, Z. M., Smith, B. E., Joughin, I. R., Porter, C., and Morin, P.: An automated, open-source pipeline for mass production of digital elevation models (DEMs) from very-high-resolution commercial stereo satellite imagery, ISPRS Journal of Photogrammetry and Remote Sensing, 116, 101-117, https://doi.org/10.1016/j.isprsjprs.2016.03.012, 2016.

Steele, M.: Arctic freshwater switchyard project: spring temperature and salinity data collected by aircraft in the Arctic Ocean, May 2006-May 2007 (NODC accession 0057319), NODC, version 1.1, https://data.nodc.noaa.gov/cgi-bin/iso?id=gov.noaa. nodc:0057319, last access: 10 October 2016, 2016.

Straneo, F. and Cenedese, C.: The dynamics of Greenland's Glacial Fjords and their role in climate, Annu. Rev. Mar. Sci., 7, 89-112, https://doi.org/10.1146/annurev-marine-010213-135133, 2015.

Straneo, F., Sergienko, O., Heimbach, P., and Hamilton, G.: U. S. CLIVAR: Climate Variability and Predictibility, White Paper 2012-2, U. S. CLIVAR Working Group on Greenland and Ice Sheet-Ocean Interactions (GRISO), Washington, DC, 2012a.

Straneo, F., Sutherland, D. A., Holland, D., Gladish, C., Hamilton, G. S., Johnson, H. L., Rignot, E., Xu, Y., and Koppes, M.: Characteristics of ocean waters reaching Greenland's glaciers, Ann. Glaciol., 53, 202-210, https://doi.org/10.3189/2012AoG60A059, 2012b.

Truffer, M. and Motyka, R. J.: Where glaciers meet water: Subaqueous melt and its relevance to glaciers in various settings, Rev. Geophys., 54, 220-239, https://doi.org/10.1002/2015RG000494, 2016.

Weertman, J.: Deformation of Floating Ice Shelves, J. Glaciol., 3, 38-42, https://doi.org/10.1017/S0022143000024710, 1957.

Wilson, N. J. and Straneo, F.: Water exchange between the continental shelf and the cavity beneath Nioghalvfjerdsbræ (79 North Glacier), Geophys. Res. Lett., 42, 7648-7654, https://doi.org/10.1002/2015GL064944, 2015.

Wilson, N.: WorldView processing scripts, Zenodo, https://doi.org/10.5281/zenodo.1068545, last access: 30 November 2017. 